\title{
THERAPEUTIC USE OF HUMAN PAPILLOMAVIRUS VACCINES IN CERVICAL LESIONS
}

\author{
Denisse Castro-Eguiluz ${ }^{1}$, Salim A. Barquet-Muñoz ${ }^{2}$, Ana C. Arteaga-Gómez ${ }^{3}$, Rosa A. Salcedo \\ Hernández ${ }^{2}$, Amelia Rodríguez-Trejo ${ }^{4}$, Dolores Gallardo-Rincón ${ }^{5}$, Juan A. Serrano-Olvera ${ }^{6}$, \\ and Carlos Aranda-Flores ${ }^{7 *}$ \\ ${ }^{1}$ Consejo Nacional de Ciencia y Tecnología (CONACYT)-Department of Clinical Research, Instituto Nacional \\ de Cancerología (INCan), Mexico City; ${ }^{2}$ CONACYT-Department of Gynecologic Oncology, INCan, Mexico City; \\ Departments of Gynecologic Oncology, ${ }^{3}$ Instituto Nacional de Perinatología, Mexico City and ${ }^{4}$ Centro Estatal \\ de Cancerología de Nayarit, Tepic, Nay., Mexico; ${ }^{5}$ Department of Medical Oncology, INCan, Mexico City; \\ ${ }^{6}$ Department of Medical Oncology, Centro Médico ABC, Mexico City; ${ }^{7}$ Department of Oncology, Hospital General \\ de México "Dr. Eduardo Liceaga," Mexico City, Mexico.
}

\begin{abstract}
Human papillomavirus (HPV) has been associated with the development of precancerous lesions of the cervix and cervical cancer (CC). Prophylactic HPV vaccination induces the development of a specific memory immune response that facilitates HPV elimination once the natural infection occurs. At present, in addition to the prophylactic vaccine, therapeutic vaccines are being developed and researched with the aim of inducing an immune response that allows the elimination of HPV-infected cells. The purpose of this study is to describe the current evidence on the use of therapeutic vaccines and their effect on cervical precancerous lesions, to establish recommendations on their clinical use. So far, the studies that have generated results have described a marginal beneficial effect of the prophylactic vaccine in the management of infection and pre-invasive lesions. Based on the evidence, continuing research on the efficacy and safety of therapeutic vaccines for the treatment of cervical intraepithelial lesions is recommended. The use of the HPV prophylactic vaccine as treatment for pre-existing lesions is not advised, but it is recommended to prevent new lesions. (REV INVEST CLIN. 2020;72(4):239-49)
\end{abstract}

Key words: Prophylaxis. Human papillomavirus. Precancerous lesion. Cytotoxicity Therapeutic vaccine.

\section{INTRODUCTION}

High risk Human Papillomavirus (HPV) infection is linked to preinvasive lesions and cancer of the cervix, vulva, vagina and anus, including cancer of the oropharynx and floor of the mouth. Identification of HPV as the etiology of precursor lesions and cervical cancer (CC) has created the opportunity for primary prevention strategies through prophylactic vaccination. Over time and with current technology, HPV structure and genome are precisely known, which open possibilities for creating vaccines for therapeutic use ${ }^{1}$.
*Corresponding author:

Carlos Aranda-Flores

E-mail: aranda_floresc@hotmail.com
Received for publication: 20-02-2020

Approved for publication: 24-04-2020

DOI: 10.24875/RIC.20000059

0034-8376 / (c) 2020 Revista de Investigación Clínica. Published by Permanyer. This is an open access article under the CC BY-NC-ND license (http://creativecommons.org/licenses/by-nc-nd/4.0/). 
Figure 1. Human papillomavirus 16 genomes. The genome has two regions that encode different proteins. Early regions (E1, E2, $E 4, E 5, E 6$, and E7) are responsible for encoding functional genes. Late regions (L1 and L2) are responsible for encoding structural genes. LCR: long control region.

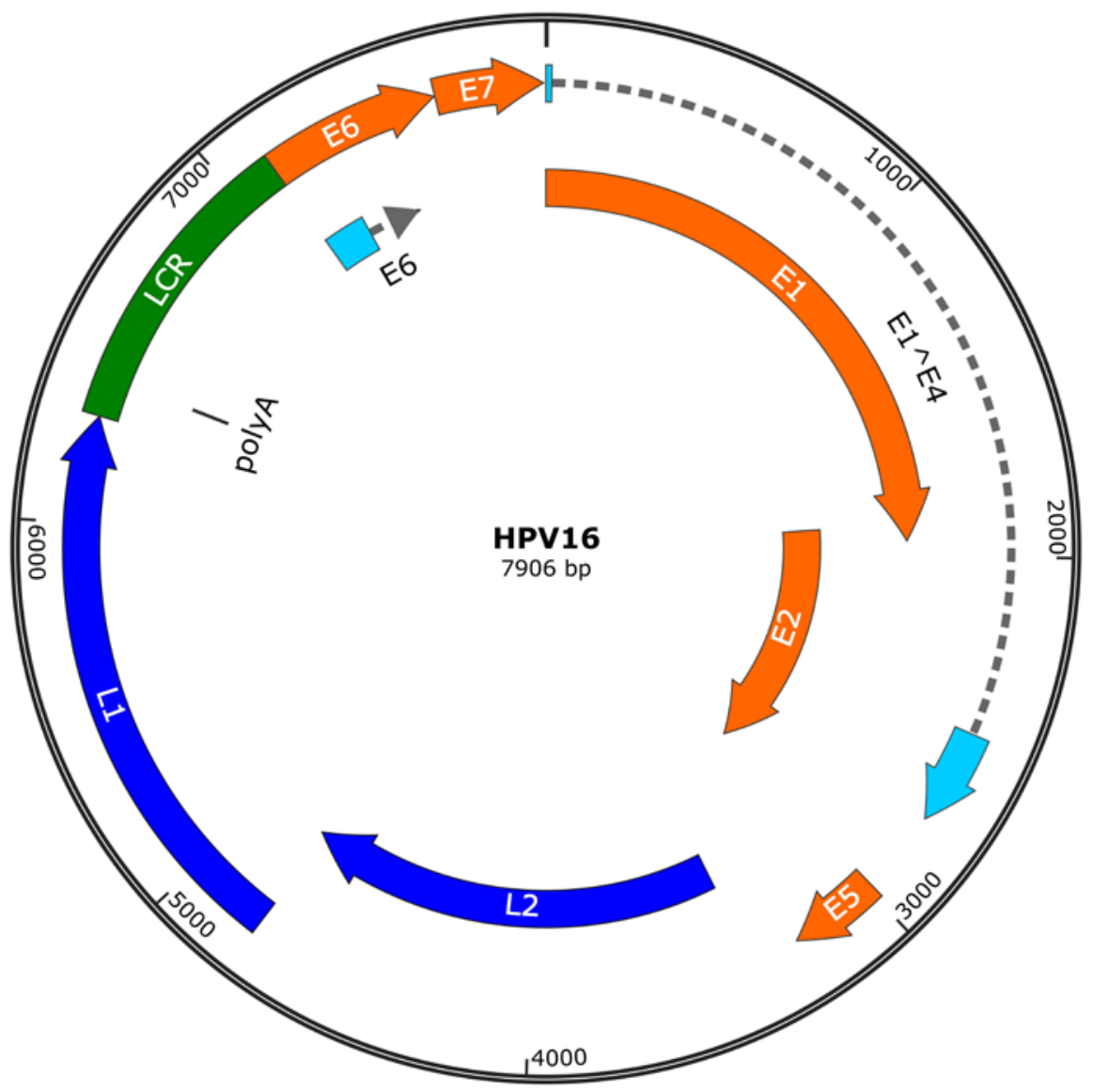

Unlike prophylactic vaccines, whose main mechanism of action is mediated by antibodies that neutralize viral particles, therapeutic vaccines can induce a cytotoxic immune response targeted against HPV-infected cells. The HPV genome consists of a circular double-stranded deoxyribonucleic acid (DNA) with three functional regions: $\mathrm{E}$ (early region), L (late region), and long control region (LCR). Determination of E gene (E1, E2, E4, E5, E6, and E7) expression can reflect the period of infection. The expression of the genes contained in the $L$ region ( $L 1$ and $L 2$ ) leads to the synthesis of the capsid structural proteins, and the region of the LCR genes constitutes the largest variation in viral genome expression (Fig. 1) ${ }^{2}$. HPV E6 and E7 oncoproteins are essential for the establishment and maintenance of the neoplasm, and given their constitutive expression once the cell is infected, they represent ideal targets for the development of therapeutic vaccines against HPV-infected cells and already established lesions. In addition, during HPV early infection E1 proteins are overexpressed, and thus, they can be considered another therapeutic target. Therefore, an ideal therapeutic vaccine should target E1, E6, or E7 proteins to induce a cytotoxic T-cell response, whose effector function is to eliminate infected or transformed cells ${ }^{3}$. Most therapeutic vaccines are intended to generate an immune response against HPV-infected cells, through antigen presentation of E6 and E7 oncoprotein by antigenpresenting cells (APCs) to T lymphocytes that in turn mount a response mediated by both helper $\mathrm{T}$ Iymphocytes and cytotoxic T lymphocytes ${ }^{4}$.

At present, there are several therapeutic vaccines that are under development and being tested in preclinical and clinical trials. These therapeutic vaccines include live vectors, inactivated viruses, live attenuated bacteria, peptides and proteins, nucleic acids, 
and cellular vaccines using dendritic cells loaded with antigen. It is important to emphasize that to assess the efficacy and safety of therapeutic vaccines, it is essential to demonstrate both their immunogenicity and safety through clinical trials.

The purpose of this review is to describe the molecular basis of HPV vaccines, as well as to examine the existing scientific evidence on the use of vaccines to generate recommendations for their clinical application. We used the NCBI-PubMed database to search for original articles that investigated these vaccines and the evidence on their safety and efficacy to prevent $\mathrm{HPV}$ infection and treat pre-cancerous lesions in infected individuals. All authors reviewed, analyzed using the GRADE system, and discussed the articles to provide recommendations.

\section{IMMUNOLOGICAL BASES OF VACCINES}

The fundamental principle of vaccination is the administration of a dead, attenuated, or component of an infectious microorganism that does not cause disease but triggers an immune response that leads to the generation of immunologic memory providing protection against the infection ${ }^{5}$. Immune system activation after the administration of therapeutic vaccines against HPV has several fundamental aspects, and it is therefore, important to understand the basic immunologic concepts occurring during vaccination.

Most vaccines are parenterally administered, including the intramuscular, subcutaneous, and intradermal routes. In general, the intradermal route generates a stronger immune response, due to the high concentration of dendritic cells within the dermis, which facilitate the recognition of the vaccine antigen. In addition, vaccination-induced local inflammation leads to the recruitment of innate immune cells, including dendritic cells and macrophages that capture the vaccine antigen and transport it to secondary lymphoid organs, where they will present it to adaptive immune cells ${ }^{6}$.

During vaccination, the first signal of activation is epithelium damage, which releases damage-associated molecular patterns. These molecules are identified by immune sentinel cells (such as macrophages, dendritic cells, and mast cells), which become activated and secrete chemotactic factors to recruit circulating cells (mainly neutrophils and monocytes). Dendritic cells and macrophages are phagocytic cells that have the ability to present antigens to T lymphocytes, and for this reason, they are called APCs. The function of APCs is to recognize the antigen, process it through phagocytosis and transport it to secondary lymphoid organs (such as regional lymph nodes or the spleen) where they present it to T lymphocytes in the context of the major histocompatibility complex (MHC) molecules. T lymphocytes, through their T-cell receptor (TCR), recognize the antigenic peptide presented in the MHC molecule by APCs. Once the TCR interacts with the MHC molecule, costimulation molecules that increase the activation signal in $T$ lymphocytes are activated. On the other hand, dendritic cells can present the unprocessed antigen to B lymphocytes in its native form. B lymphocytes are APCs, so they also capture, process, and present the antigen to $T$ lymphocytes. Once T lymphocytes are activated, they will produce cytokines that will modulate the immune response against the specific antigen. These cytokines have effects on innate and adaptive immune cells. The cytokine signal that the $B$ cells receive will drive them to clonal expansion, and some of the daughter cells will differentiate into antibody-producing plasma cells. Depending on the type of cytokines present in the microenvironment, B lymphocytes are going to switch isotype and undergo somatic hypermutation in their B-cell receptor genes, to produce the antibody isotype that best responds to the antigen in question and with higher affinity. Part of both $\mathrm{T}$ and $\mathrm{B}$ lymphocytes will become memory cells, which will be dormant until they meet their specific antigen again, in this case, the vaccine-contained antigen ${ }^{7}$. Thus, if a vaccine manages to establish this type of response, it will generate immunological memory, which will allow the immediate activation of $T$ and $B$ lymphocytes when the natural infection occurs, in this case with $\mathrm{HPV}^{8}$. When presented with HPV, memory B lymphocytes will be activated and transformed into antibodyproducing plasma cells to neutralize the viral particles. If viral particles infect cells, cytotoxic T lymphocytes must, then, exert their function of recognizing and eliminating virus-infected cells ${ }^{9}$.

Vaccines can therefore induce a humoral immune response through antibodies produced by B lymphocytes, and a cellular immune response through cytotoxic T lymphocytes. Both types of responses will be 
orchestrated by cytokines produced by helper T lymphocytes. Once the infectious agent is eliminated, effector cells die by apoptosis and the memory cells that were generated during the immune response will remain in a quiescent state, until their next exposure to $\mathrm{HPV}^{7}$. While humoral immune response has an important preventive role, cell-mediated immune responses play a crucial role in the regression of precancerous lesions.

\section{TYPES OF THERAPEUTIC VACCINES AGAINST HPV}

At present, therapeutic vaccines are based on nucleic acids, peptides, proteins, viruses, bacteria, and dendritic cells. Each vector has specific characteristics that offer advantages and disadvantages that are currently being studied (Table 1 ).

\section{Vectors based on nucleic acids}

These vectors are composed of nucleic acids that will use the machinery of the host cells to translate the genetic material into antigenic peptides that will generate a response by the immune system. Based on their nature, they can be DNA or ribonucleic acid (RNA) vectors.

\section{DNA}

Vaccines that use DNA as a vector require the use of plasmids so that the protein can be encoded by the host cell. The plasmid contains a viral promoter, the gene of interest, and a polyadenylation/transcription termination sequence. The plasmid can transfect not only the tissue cells where the vaccine was injected but also APCs, such as macrophages and dendritic cells that will synthesize, process, and present the antigenic peptide. This way, the inflammatory response and antigen presentation to cytotoxic $\mathrm{T}$ lymphocytes in MHC-I molecules are initiated, as previously described ${ }^{10}$. APCs can also phagocytize infected cells and present the antigen to $T$ helper lymphocytes in MHC-II molecules.

The main advantages of these vaccines are their manufacturing simplicity, thermostability, the possibility of repeating doses without lowering their effectiveness, their ability to induce cellular immune responses, as well as their safety and tolerance in human subjects ${ }^{11}$. The main disadvantage of these vaccines is their low immunogenicity, since naked DNA transfection is inefficient in vivo ${ }^{12}$. This disadvantage can be corrected by incorporating into the vector genes that modulate cell pathways ${ }^{13}$. In addition, transfection efficiency can be increased with small electrical pulses at the site of application, which induces electroporation of the cells and entry of the vector into the host cell. This mechanism also favors local inflammation, with the production of cytokines that will act as adjuvants in immune response induction ${ }^{14}$.

\section{RNA}

RNA can be derived from different types of viruses. Vaccines that use RNA as a vector only need to cross the cell membrane, as it is not required for them to incorporate their genome into the host's DNA, which increases the likelihood of transfection. These types of vaccines activate toll-like receptors (TLRs) in innate immune cells that recognize nucleic acid ligands, such as TLR3, TLR7, TLR8, and TLR915. An advantage of RNA vaccines is that repeated application is possible. Their main disadvantage is that they are extremely unstable and have not currently been used in clinical settings ${ }^{16}$.

\section{Vectors based on peptides and proteins}

This type of vectors uses peptides, amino acid sequences of different sizes, and proteins, antigens that will be recognized by immune cells. They can be classified into peptides (short amino acid chains) and complex proteins.

\section{Peptides}

Peptide-based vaccines in general have the advantage of being stable and safe and can be easily produced in large scale. They can be constituted of short peptides (specific epitopes) or long peptides ${ }^{17}$.

Short peptides ( $<15$ amino acids) do not need to be processed by APCs and can exogenously bind to MHC Class I molecules in nucleated cells. However, for the interaction of MHC-peptide with TCR to activate T lymphocytes, it also requires costimulation molecules; without this second stimulus, T lymphocytes will not 
Table 1. Types of vectors used in therapeutic vaccines against premalignant cervical lesions

\begin{tabular}{|c|c|c|c|c|}
\hline Vector & Mechanism & Advantages & Disadvantages & $\begin{array}{l}\text { Trials testing } \\
\text { vaccine }\end{array}$ \\
\hline DNA & $\begin{array}{l}\text { Transfection to somatic cells } \\
\text { or tissue-resident APCs. }\end{array}$ & $\begin{array}{l}\text { Simple, low cost, } \\
\text { thermostable, safe, } \\
\text { tolerable, induces humoral } \\
\text { and cellular immunity. }\end{array}$ & $\begin{array}{l}\text { Poorly immunogenic. } \\
\text { Needs the use of other } \\
\text { strategies to improve } \\
\text { immunogenicity. }\end{array}$ & $\begin{array}{l}\text { Phase II trials. } \\
\text { Ongoing phase } \\
\text { III trial. }\end{array}$ \\
\hline RNA & $\begin{array}{l}\text { Direct transfection to host } \\
\text { cell. }\end{array}$ & $\begin{array}{l}\text { Because it needs to cross the } \\
\text { cell membrane, the } \\
\text { possibility of transduction } \\
\text { improves. }\end{array}$ & Unstable. & $\begin{array}{l}\text { Has not been } \\
\text { tested in } \\
\text { clinical trials. }\end{array}$ \\
\hline Peptides & $\begin{array}{l}\text { Short peptides ( }<20 \text { amino } \\
\text { acids) bind to MHC-I } \\
\text { molecules. } \\
\text { Long peptides ( }>20 \text { amino } \\
\text { acids) are processed and } \\
\text { presented by APCs. }\end{array}$ & $\begin{array}{l}\text { Safe, stable, feasible } \\
\text { production. }\end{array}$ & $\begin{array}{l}\text { Poorly immunogenic; } \\
\text { therefore, they require } \\
\text { adjuvants. }\end{array}$ & $\begin{array}{l}\text { Phase I trial. } \\
\text { Ongoing phase } \\
\text { II trial. }\end{array}$ \\
\hline Proteins & $\begin{array}{l}\text { Protein antigens are } \\
\text { phagocytized and presented } \\
\text { through MHC-II molecules, } \\
\text { which favors an antibody } \\
\text { response. }\end{array}$ & $\begin{array}{l}\text { Contain multiple epitopes } \\
\text { that can be recognized } \\
\text { by TCR. }\end{array}$ & $\begin{array}{l}\text { Does not induce a cytotoxic } \\
\text { response by CD8 T cells. }\end{array}$ & Phase II trial. \\
\hline Viral & $\begin{array}{l}\text { Non-essential viral genes are } \\
\text { replaced by genes that } \\
\text { encode for protein antigens } \\
\text { of interest. They stimulate } \\
\text { humoral and cellular } \\
\text { responses. } \\
\text { The most commonly used are: } \\
\text { - Adenovirus } \\
\text { - Poxvirus }\end{array}$ & $\begin{array}{l}\text { Viruses have the ability to } \\
\text { use the host cell to translate } \\
\text { their own genetic material. } \\
\text { The viruses may elicit an } \\
\text { antibody response, and the } \\
\text { proteins they produce may } \\
\text { be presented on MHC-I } \\
\text { molecules to elicit a cellular } \\
\text { response. }\end{array}$ & $\begin{array}{l}\text { A pre-existing antibody in the } \\
\text { host may neutralize the viral } \\
\text { vector. }\end{array}$ & $\begin{array}{l}\text { Phases I } \\
\text { and II trials. }\end{array}$ \\
\hline Bacterial & $\begin{array}{l}\text { Bacteria have a great ability } \\
\text { to induce both, innate and } \\
\text { adaptive immune responses. } \\
\text { They are recognized, } \\
\text { processed and presented } \\
\text { by APCs. }\end{array}$ & $\begin{array}{l}\text { Low-cost production, stable } \\
\text { and can be produced at a } \\
\text { large scale. } \\
\text { They preserve their ability to } \\
\text { synthesize antigens. Can be } \\
\text { eliminated with antibiotics. }\end{array}$ & $\begin{array}{l}\text { Live bacterial vectors need } \\
\text { refrigeration. }\end{array}$ & $\begin{array}{l}\text { Phases I } \\
\text { and II trials. }\end{array}$ \\
\hline $\begin{array}{l}\text { Dendritic } \\
\text { cells }\end{array}$ & $\begin{array}{l}\text { Dendritic cells are loaded with } \\
\text { antigenic peptides ex vivo. } \\
\text { Dendritic cells are then } \\
\text { reintroduced to the host, } \\
\text { where they present the } \\
\text { antigens to T cells. }\end{array}$ & $\begin{array}{l}\text { Dendritic cells are important } \\
\text { for immune response } \\
\text { induction and are regarded } \\
\text { as the most efficient APCs. }\end{array}$ & $\begin{array}{l}\text { Difficulty in production at a } \\
\text { large scale due to the cost, } \\
\text { time and work required for } \\
\text { their production; must be } \\
\text { individualized for each } \\
\text { patient; and their half-life } \\
\text { is limited. }\end{array}$ & $\begin{array}{l}\text { Phase } \\
\text { I trials. }\end{array}$ \\
\hline
\end{tabular}

DNA: deoxyribonucleic acid; RNA: ribonucleic acid; MHC: major histocompatibility complex; APC: antigen presenting cell.

become activated, and thus a protective immune response will not be generated ${ }^{18}$. Long synthetic peptides (> 20 amino acids) are protein chains that cannot bind exogenously to MHC molecules and must therefore, first be processed or digested by cells to generate peptides of appropriate size that can bind to $\mathrm{MHC}$ molecules and be presented to $\mathrm{T}$ Iymphocytes. These vaccines have the disadvantage of being poorly immunogenic and therefore, require some type of adjuvant, although they are safe ${ }^{19,20}$. 


\section{Proteins}

These vaccines contain numerous epitopes that will be recognized by helper and cytotoxic T lymphocytes, with a higher probability of activating various clones of T lymphocytes. However, due to their size and complexity, protein vaccines must be first phagocytized by APCs to be presented with MHC-II molecules to helper $\mathrm{T}$ lymphocytes, favoring an antibody response rather than cytotoxic responses ${ }^{21}$.

\section{Vectors based on viruses and bacteria}

\section{Virus}

Viruses are highly attractive vectors for vaccine development due to their ability to use the host cell machinery to synthesize both their genetic material and proteins to generate new viral particles and propagate. For the safety of this type of vaccines, virulence genes must be eliminated or replaced by other genes selected to encode proteins that increase immunogenicity and modulate the type of response that is sought to be generated with the vaccine. One disadvantage of this type of vaccines is that the presence of neutralizing antibodies in the host can prevent access of the viral vector to the cell and prevent a cytotoxic response from being generated in the subject.

The most commonly used viral vectors include adenovirus and vaccinia-type viruses (e.g., Ankara Vaccinia Modified or MVA).

1. Adenoviruses. These have a high level of tropism for many types of cells, which is why they have been the pioneer viruses used in the manufacture of vaccines with viral vectors. Adenoviruses have five early regions. The E1A region activates other viral genes that are critical for viral replication. By eliminating these genes, viral replication is defective, making these vectors safe for humans. Once incorporated into the nucleus, these viruses persist in an episomal form, without being incorporated into the host cell genome, which minimizes the risk of oncogenesis. One disadvantage of these viruses is that they are ubiquitous in humans and there is pre-existing immunity that ranges between $60 \%$ and $90 \%$ depending on the geographical region ${ }^{22}$.
2. Poxviruses. Among these, the most commonly used for vaccine production are vaccinia-type viruses. These viruses have a long and stable genome, with very strong transcriptional and translational capacity. Their life cycle occurs entirely in the cell cytoplasm, which minimizes the risk of mutagenesis. They have high tropism for monocytes and myeloid cells, including APCs, which represent an advantage in the induction of an efficient immune response. They are easy to manufacture, inexpensive and can be applied through the intradermal, intranasal, intravaginal, and intra-rectal routes $^{23}$.

\section{Bacteria}

Vectors that use live attenuated bacteria have a large capacity to induce local and systemic immunity, both humoral and cellular, since they are the best simulators of a natural infection. Once the vaccine is administered, pathogen-associated molecular patterns (PAMPs) such as lipopolysaccharide, peptidoglycan, and flagellin, among others, are recognized by innate immune cell TLRs and this initiates the inflammatory process. Bacteria identified by innate cells, such as macrophages and tissue resident dendritic cells, will be phagocytized and subsequently presented to $T$ lymphocytes, as previously described ${ }^{24,25}$.

The most commonly used vector in this type of vaccines is the Listeria monocytogenes bacterium which, being an intracellular pathogen, can induce cytotoxic T lymphocyte responses. Hence, once the bacterium is endocytosed, it has a mechanism that allows it to leave the endosome toward the cytosol; the proteins that the bacterium synthesizes in the cytosol will be processed and presented in the context of MHC-I molecules for recognition by cytotoxic T lymphocytes. Vaccines with live attenuated bacteria are relatively easy to produce and can be orally administered.

\section{Dendritic cell-based vectors}

Dendritic cells play a highly important role in immune response induction and are considered the most efficient APCs ${ }^{26}$. The mechanism of this type of vaccines consists in differentiating dendritic cells from the individual ex vivo; subsequently, they are cocultured with the antigen and with cytokines that favor 
the activation of dendritic cells. Once the "antigenloaded" dendritic cells are obtained, they are administered to the individual. Dendritic cells then reach secondary lymphoid organs where they will present the antigen to T lymphocytes to generate a response. The main disadvantage of dendritic cell-based vaccines is the difficulty to produce them in large scale due to the cost, time, and work implied by this process, in addition to having a limited half-life.

\section{SCIENTIFIC EVIDENCE ON THE EFFICACY OF HPV THERAPEUTIC VACCINE}

\section{Nucleic acid-based vaccines}

Several clinical studies are currently being conducted to evaluate the efficacy and therapeutic safety of the vaccine that uses DNA as a vector in humans.

The HPV vaccine Gx-188E, in a Phase I clinical trial, demonstrated its safety and tolerance in nine of 11 patients with cervical intraepithelial neoplasia (CIN) 3, and was shown to be able to induce significant cellular immunity. At 36 weeks of follow-up, complete regression of the histological lesions was observed in seven out of nine patients ${ }^{27}$.

The VGX-3100 DNA vaccine is the first therapeutic vaccine that has shown efficacy against HPV 16 and 18-associated CIN 2 or 3 . This vaccine consists of the mixture of two DNA plasmids coding for the genes of E6 and E7 antigens of said viruses. Its efficacy, safety, and immunogenicity were assessed in a randomized, double-blind, and placebo-controlled phase Ilb clinical trial that included 167 patients. Efficacy in the regression of CIN 2/3 to CIN 1 or normal histopathology was assessed 36 weeks after the first dose. The study showed that $49.5 \%$ of patients treated with VGX-3100 versus $30.6 \%$ of those treated with placebo, achieved histopathological regression (difference of $19 \%$; $95 \%$ confidence interval $[\mathrm{Cl}]: 1.4-36.6 ; \mathrm{p}=0.034$ ). In addition, $40.2 \%$ of patients treated with the vaccine versus $14.3 \%$ of those treated with placebo (difference of $25.9 \%$; $95 \% \mathrm{Cl}: 8.0-39.2 ; \mathrm{p}=0.003$ ) achieved concomitant histopathological regression and viral clearance. This vaccine is currently being assessed in a Phase III study ${ }^{27}$.
At present, there are other vaccines that use DNA as a vector and that are at different phases of research, although to date, the one with most evidence on efficacy and safety is VGX-3100.

\section{Peptide and protein-based vaccines}

The HPV16-SLP vaccine was assessed in a randomized, placebo-controlled Phase II clinical trial. The objective of this study was to evaluate the ability of HPV16-SLP vaccine to generate a specific T-cell response. It included 50 patients with HPV 16-associated low-grade lesions, who were randomized to receive the vaccine or placebo. Among the vaccinated patients, 97\% generated a specific immune response against HPV, with scarce side effects ${ }^{28}$.

The applicability of the therapeutic HPV vaccine based on peptides has also been assessed in multiple clinical trials in patients with recurrent CC, recurrent head-and-neck cancer, as well as in intraepithelial vulvar lesions, showing promising results.

\section{Virus and bacteria-based vaccines}

A Phase I/Ila study, which involved a total of $17 \mathrm{pa}-$ tients with HPV 16 infection and CIN 3, assessed the clinical safety and efficacy of oral vaccination using Lactobacillus casei attenuated bacterial vectors. In this study, none of the participants showed serious adverse events, and some patients showed an increase in T cell-mediated response. Cytological regression to a low-grade lesion was observed in $70 \%$ of patients ${ }^{29}$.

With regard to viral vector-based vaccines, the TG4001 vaccine is a suspension of modified Ankara virus viral particles. Its safety and efficacy were assessed in a Phase II study, which included 21 patients diagnosed with HPV 16-associated CIN 2 and 3. The patients received a subcutaneous TG4001 injection. At 6 months' follow-up, ten of the 21 patients (48\%) showed regression to low-grade lesions, and eight of the ten responders had HPV 16 viral DNA clearance ${ }^{30}$.

Other therapeutic vaccines based on modified Ankara virus have been studied. In a Phase II study involving 78 patients with $\mathrm{CIN} \mathrm{1,2,} \mathrm{and} \mathrm{3,} \mathrm{from} \mathrm{the} \mathrm{Mexican}$ Institute of Social Security (IMSS - Instituto Mexicano 
del Seguro Social) in Mexico City, subjects were administered the MVA E2 vaccine. Thirty-six patients received the vaccine injected directly into the cervix, and 42 were treated with cryosurgery. During followup, 34 of 36 patients who received the vaccine showed regression of the lesion, and all patients in the vaccinated group developed an immune response ${ }^{16}$.

In a multicenter study carried out in Mexico, 1356 patients ( 1176 women with HPV-associated CIN 1 to 3 and 180 men) who received the MVA E2 vaccine were included in the study. In this study, efficacy in the regression of CIN 1, 2, and 3 was assessed. During follow-up, $89.3 \%$ of women exhibited complete clearance of histological lesions. In men, all HPV-produced lesions were cleared. This study showed that the MVA E2 vaccine stimulates the immune response and generates regression of intraepithelial lesions when locally applied ${ }^{31}$.

\section{Dendritic cell-based vaccines}

A Phase I study assessed the safety, toxicity, and immunogenicity of dendritic cell-based vaccines in 14 patients with Stage IB to IIA CC. The study demonstrated safety and tolerance with few local reactions, as well as an increase in E7-specific T lymphocytes ${ }^{32}$. Evidence from studies has demonstrated that this type of vaccine is well tolerated and triggers an adaptive immune-specific response. The response of preimmune dendritic cells stimulated with HPV 16 E6 or E7 has induced specific immune response rates to E6 in $63 \%$ of patients and to E7 in $58 \%$.

\section{Evidence on the efficacy of prophylactic vaccines with therapeutic use}

At present, the effectiveness of prophylactic vaccines in preventing intraepithelial lesions is well known. The studied vaccines include bivalent (against HPV 16 and 18), tetravalent (against HPV 6, 11, 16, and 18), and nonavalent (against HPV 6, 11, 16, 18, 31, 33, 45,52 , and 58 ) vaccines. In addition, the therapeutic use of these vaccines has been studied in patients with preexisting HPV infection or with premalignant lesions.

Evidence on the effectiveness of prophylactic vaccines for lesion regression or viral clearance is limited. In a
Phase III study, in which the efficacy of the tetravalent vaccine on the regression of HPV infection was assessed, reduction of lesions, including CC in situ, was generally found (17.7\%, 95\% Cl: 5.21\%-28.7\%). In high-grade lesions, there was a non-statistically significant reduction ${ }^{33}$. In another placebo-controlled clinical trial, where more than 18,000 patients were included, the efficacy of the tetravalent vaccine was assessed. In its analysis of patients with the presence of HPV or lesions, a decrease in the presence of $\mathrm{CIN} \mathrm{2+} \mathrm{cervical} \mathrm{lesions} \mathrm{was} \mathrm{found} \mathrm{in} \mathrm{vaccinated}$ patients in comparison with the placebo group (18.7\% reduction; 95\% Cl: <0.0\%-40.7\%; $\mathrm{p}<0.001$ ). In addition, a decrease in high-grade vaginal and vulvar lesions was found ( $22.1 \%$ reduction; $95 \% \mathrm{Cl}: 0.0-84.6 \%$; $\mathrm{p}=0.053)^{34}$. In the FUTURE trial, in the intention-totreat analysis, in the population defined by patients who had infection or HPV $6,11,16$, and 18-associated disease, a $20 \%$ reduction $(95 \% \mathrm{Cl} 8-31$ ) in cervical lesions was found regardless of the virus type ${ }^{35}$. Another study, whose purpose was to determine whether vaccination against HPV 16/18 increased the percentage of viral infection clearance in patients already infected, included 2189 women between 18 and 25 years of age, with a follow-up of at least 6 months. A clearance rate of $33.4 \%$ was found in the group of vaccinated patients versus $31.6 \%$ in the control group (2.5\% difference, $95 \% \mathrm{Cl}:-9.8 \%-13.5 \%)^{36}$. Finally, in a 2018 Cochrane review, in a sub-analysis conducted in patients with a positive serological status for HPV, no benefit was found with the application of the vaccine in terms of viral clearance $(R R=1.10$; 95\% Cl: 0.88-1.36). In addition, a tendency toward a higher risk of high-grade lesions was found, and lower efficacy of the vaccine in patients with preexisting infection in comparison with non-vaccinated patients ${ }^{37}$.

This poor benefit of the prophylactic vaccine in the management of established lesions is most likely because this type of vaccine generates a neutralizingantibody response to prevent cell infection; however, once the cell is infected, antibody-mediated immunity will only have an effect on extracellular viral particles, but will have no effect on already infected cells. In conclusion, the benefit of prophylactic vaccines in the management of infection and pre-invasive lesions is difficult to assess; results are contradictory and in those where some benefit has been shown, it is marginal. 
Table 2. Ongoing clinical trials assessing the efficacy and safety of therapeutic vaccines against human papillomavirus

\begin{tabular}{|c|c|c|c|c|c|}
\hline $\begin{array}{l}\text { Vaccine ID } \\
\text { (Manufacturer) }\end{array}$ & Antigens & Structure & Study design & $\begin{array}{l}\text { Estimated study } \\
\text { completion date }\end{array}$ & $\begin{array}{l}\text { Clinical } \\
\text { Trials ID }\end{array}$ \\
\hline $\begin{array}{l}\text { GX-188E } \\
\text { (Genexine, Inc.) }\end{array}$ & $\begin{array}{l}\text { HPV } 16 \text { and } \\
18, E 6 \text { and E7. }\end{array}$ & $\begin{array}{l}\text { Plasmid encoding } \\
\text { the HPV } 16 \text { and } \\
18 \text { E6/E7 fusion } \\
\text { protein linked to } \\
\text { the immune- } \\
\text { enhancer FLT3L. }\end{array}$ & $\begin{array}{l}\text { Phase II study in } \\
\text { patients with CIN } \\
2 / 3 \text {, and HPV } 16 \\
\text { and } 18 \text { in Eastern } \\
\text { Europe. } \\
120 \text { estimated } \\
\text { patients. }\end{array}$ & August 2018 & NCT02596243 \\
\hline $\begin{array}{l}\text { GX-188E } \\
\text { (Genexine, Inc.) }\end{array}$ & $\begin{array}{l}\text { HPV } 16 \text { and } \\
18, E 6 \text { and E7. }\end{array}$ & $\begin{array}{l}\text { Plasmid encoding } \\
\text { the HPV } 16 \text { and } \\
18 \text { E6/E7 fusion } \\
\text { protein linked to } \\
\text { the immune- } \\
\text { enhancer FLT3L. }\end{array}$ & $\begin{array}{l}\text { Phase II trial in } \\
\text { patients with CIN } \\
3 \text { and HPV } 16 \text { and } \\
18 \text { in South } \\
\text { Korea. } \\
72 \text { estimated } \\
\text { patients. }\end{array}$ & Completed & NCT02139267 \\
\hline $\begin{array}{l}\text { pNGVL4a-CRT/E7 } \\
\text { (detox) (Sidney } \\
\text { Kimmel } \\
\text { Comprehensive } \\
\text { Cancer Center at } \\
\text { Johns Hopkins.) }\end{array}$ & HPV 16 E7. & $\begin{array}{l}\text { Plasmid encoding } \\
\text { calreticulin linked } \\
\text { to a detox form of } \\
\text { HPV type 16-E7 } \\
\text { antigen. }\end{array}$ & $\begin{array}{l}\text { Phase I study in } \\
\text { patients with CIN } \\
2 / 3 \text { and HPV } 16 . \\
39 \text { estimated } \\
\text { patients. }\end{array}$ & Completed & NCT00988559 \\
\hline $\begin{array}{l}\text { pNGVL4a-Sig/ } \\
\text { E7(detox)/HSP70 } \\
\text { and TA-HPV } \\
\text { (Sidney Kimmel } \\
\text { Comprehensive } \\
\text { Cancer Center at } \\
\text { Johns Hopkins.) }\end{array}$ & $\begin{array}{l}\text { HPV } 16 \text { E7 } \\
\text { and HPV } 16 \text { and } \\
18 \mathrm{E} 6 \text { and } \mathrm{E} 7 .\end{array}$ & $\begin{array}{l}\text { Plasmid encoding } \\
\text { the signal peptide } \\
\text { (pNGVL4a-Sig), } \\
\text { a detox form of } \\
\text { HPV-16 antigen E7, } \\
\text { linked to HSP70. } \\
\text { TA-HPV is a live } \\
\text { recombinant } \\
\text { vaccinia virus } \\
\text { expressing HPV } \\
\text { type } 16 \text { and } 18 \text { E6/ } \\
\text { E7 proteins. }\end{array}$ & $\begin{array}{l}\text { Phase I study in } \\
\text { patients with CIN } \\
3 \text { and HPV16 in } \\
\text { combination with } \\
\text { topical imiquimod. } \\
48 \text { estimated } \\
\text { patients. }\end{array}$ & June 2020 & NCT00788164 \\
\hline $\begin{array}{l}\text { TVGV-1 } \\
\text { (THEVAX Genetics } \\
\text { Vaccine Co.) }\end{array}$ & HPV 16 E7 & $\begin{array}{l}\text { Peptide sequence } \\
\text { of HPV } 16 \text { E7 } \\
\text { protein fused to } \\
\text { Pseudomonas } \\
\text { aeruginosa } \\
\text { exotoxin A (PE) } \\
\text { and ER retention } \\
\text { signal (KDEL) } \\
\text { combined with } \\
\text { immunoadjuvant } \\
\text { GPI-0100, a } \\
\text { saponin derivative. }\end{array}$ & $\begin{array}{l}\text { Phase lla study in } \\
\text { patients with } \\
\text { high-grade } \\
\text { induced cervical } \\
\text { lesion. } \\
51 \text { estimated } \\
\text { patients. }\end{array}$ & September 2018 & NCT02576561 \\
\hline $\begin{array}{l}\text { PepCan (University } \\
\text { of Arkansas for } \\
\text { Medical Sciences.) }\end{array}$ & HPV 16 E6 & $\begin{array}{l}\text { Four synthetic } \\
\text { peptides covering } \\
\text { HPV } 16 \text { E6 protein } \\
\text { combined with a } \\
\text { Candida skin-test } \\
\text { reagent (Candin) } \\
\text { as adjuvant. }\end{array}$ & $\begin{array}{l}\text { Phase II study } \\
\text { in patients } \\
\text { with high-grade } \\
\text { cervical } \\
\text { intraepithelial } \\
\text { lesion. } \\
125 \text { estimated } \\
\text { patients. }\end{array}$ & August 2020 & NCT02481414 \\
\hline
\end{tabular}

ID: identification; HPV: human Papillomavirus; FLT3L: Fms-like tyrosine kinase-3 ligand; CIN: cervical intraepithelial neoplasia; HSP70: heat shock protein-70; ER: endoplasmic reticulum. 


\section{CONCLUSIONS}

There are no Phase III studies assessing the efficacy of therapeutic vaccines against intraepithelial lesions; therefore, there can be no recommendations for their standard use. However, there are Phase II studies, which have shown their safety. Various clinical trials are currently underway, evaluating the effectiveness, and safety of therapeutic vaccines against HPV infections and pre-invasive lesions (Table 2). Therefore, their results will eventually be announced and recommendations on the use of therapeutic vaccines as part of standard treatments will be issued.

The benefit of prophylactic vaccines in the management of infection and pre-invasive lesions is difficult to assess; results are conflicting, and only marginal benefits have been shown. It is important to emphasize that replacement of the standard treatment of a high-grade lesion with the application of the prophylactic vaccine is currently not indicated.

\section{RECOMMENDATIONS}

1. Regarding efficacy, the use of therapeutic vaccines for the treatment of cervical intraepithelial lesions should be exclusively within the context of research. Quality of evidence: Low. Strength of recommendation: Weak in favor of its use.

2. Regarding safety, the use of therapeutic vaccines for the treatment of cervical intraepithelial lesions must be exclusively within a context of research. Quality of evidence: Moderate. Strength of recommendation: Weak in favor of its use.

3. The HPV prophylactic vaccine should not be used in the treatment of preexisting cervical intraepithelial lesions; it can be applied to prevent new lesions (cervical, vulvar or vaginal, and anal). Quality of evidence: Low. Strength of recommendation: Weak against its use.

\section{REFERENCES}

1. zur Hausen H. Papillomaviruses and cancer: from basic studies to clinical application. Nat Rev Cancer. 2002;2:342-50.
2. Abreu AL, Souza RP, Gimenes F, Consolaro ME. A review of methods for detect human papillomavirus infection. Virol J. 2012;9:262-70.

3. Harper DM, Williams KB. Prophylactic HPV vaccines: current knowledge of impact on gynecologic premalignancies. Discov Med. 2010;10:7-17.

4. Yang A, Jeang J, Cheng K, Cheng T, Yang B, Wu TC, et al. Current state in the development of candidate therapeutic HPV vaccines. Expert Rev Vaccines. 2016;15:989-1007.

5. Vaccine Assessment and Monitoring Team, World Health Organization. WHO-recommended Standards for Surveillance of Selected Vaccine-preventable Diseases. Geneva, Switzerland: Vaccine Assessment and Monitoring Team, World Health Organization; 2003.

6. Clements JD, Freytag LC. Parenteral vaccination can be an effective means of inducing protective mucosal responses. Clin Vaccine Immunol. 2016;23:438-41.

7. Clem AS. Fundamentals of vaccine immunology. J Glob Infect Dis. 2011;3:73-8.

8. Pulendran B, Ahmed R. Immunological mechanisms of vaccination. Nat Immunol. 2011;12:509-17.

9. Zhang L, Wang W, Wang S. Effect of vaccine administration modality on immunogenicity and efficacy. Expert Rev Vaccines. 2015;14:1509-23.

10. Barber GN. Cytoplasmic DNA innate immune pathways. Immunol Rev. 2011;243:99-108.

11. Ledwith BJ, Manam S, Troilo PJ, Barnum AB, Pauley CJ, Griffiths TG 2nd, et al. Plasmid DNA vaccines: investigation of integration into host cellular DNA following intramuscular injection in mice. Intervirology. 2000;43:258-72.

12. Stratford R, Douce G, Zhang-Barber L, Fairweather N, Eskola J, Dougan G. Influence of codon usage on the immunogenicity of a DNA vaccine against tetanus. Vaccine. 2000;19: 810-5.

13. Lin CT, Tsai YC, He L, Yeh CN, Chang TC, Soong YK, et al. DNA vaccines encoding IL-2 linked to HPV-16 E7 antigen generate enhanced E7-specific CTL responses and antitumor activity. Immunol Lett. 2007;114:86-93.

14. Lu S. Heterologous prime-boost vaccination. Curr Opin Immunol. 2009;21:346-51.

15. Diebold SS, Kaisho T, Hemmi H, Akira S, Reis E, Sousa C. Innate antiviral responses by means of TLR7-mediated recognition of single-stranded RNA. Science. 2004;303:1529-31.

16. Kim TW, Hung CF, Juang J, He L, Hardwick JM, Wu TC. Enchancement of suicidal DNA vaccine potency by delaying suicidal DNAinduced cell death. Gene Ther. 2004;11:336-42.

17. Hung CF, Wu TC, Monie A, Roden R. Antigen-specific immunotherapy of cervical and ovarian cancer. Immunol Rev. 2008 222:43-69.

18. van der Burg SH, Bijker MS, Welters MJ, Offringa R, Melief CJ. Improved peptide vaccine strategies, creating synthetic artificial infections to maximize immune efficacy. Adv Drug Deliv Rev. 2006:58:916-30.

19. Bijker MS, van den Eeden SJ, Franken KL, Melief CJ, van der Burg $\mathrm{SH}$, Offringa R. Superior induction of anti-tumor CTL immunity by extended peptide vaccines involves prolonged, DC-focused antigen presentation. Eur J Immunol. 2008;38:1033-42

20. Lin K, Doolan K, Hung CF, Wu TC. Perspectives for preventive and therapeutic HPV vaccines. J Formos Med Assoc. 2010; 109:4-24.

21. Simsova $M$, Sebo $P$, Leclerc $C$. The adenylate cyclase toxin from Bordetella pertussis-a novel promising vehicle for antigen delivery to dendritic cells. Int J Med Microbiol. 2004; 293:571-6.

22. Ewer KJ, Lambe T, Rollier CS, Spencer AJ, Hill AV, Dorrell L. Viral vectors as vaccine platforms: from immunogenicity to impact. Curr Opin Immunol. 2016;41:47-54.

23. Moss B. Genetically engineered poxviruses for recombinant gene expression, vaccination, and safety. Proc Natl Acad Sci. 2002;93:11341-8.

24. Cossart P, Pizarro-Cerdá J, Lecuit M. Invasion of mammalian cells by Listeria monocytogenes: functional mimicry to subvert cellular functions. Trends Cell Biol. 2003;13:23-31.

25. Dietrich G, Spreng S, Favre D, Viret JF, Guzman CA. Live attenuated bacteria as vectors to deliver plasmid DNA vaccines. Curr Opin Mol Ther. 2003;5:10-9.

26. Lee SJ, Yang A, Wu TC, Hung CF. Immunotherapy for human papillomavirus-associated disease and cervical cancer: review of clinical and translational research. J Gynecol Oncol. 2016;27:e51.

27. Trimble CL, Morrow MP, Kraynyak KA, Shen X, Dallas M, Yan J, et al. Safety, efficacy, and immunogenicity of VGX-3100, a 
therapeutic synthetic DNA vaccine targeting human papillomavirus 16 and $18 \mathrm{E} 6$ and E7 proteins for cervical intraepithelial neoplasia 2/3: a randomised, double-blind, placebo-controlled phase 2 b trial. Lancet. 2015;386:2078-88.

28. de Vos van Steenwijk PJ, Ramwadhdoebe TH, Löwik MJ, van der Minne CE, Berends-van der Meer DM, Fathers LM, et al. A placebocontrolled randomized HPV16 synthetic long-peptide vaccination study in women with high-grade cervical squamous intraepithelial lesions. Cancer Immunol Immunother. 2012;61:1485-92.

29. Kawana K, Adachi K, Kojima S, Taguchi A, Tomio K, Yamashita $A$, et al. Oral vaccination against HPV E7 for treatment of cervical intraepithelial neoplasia grade 3 (CIN3) elicits E7-specific mucosal immunity in the cervix of CIN3 patients. Vaccine. 2014;32:6233-9.

30. Brun JL, Dalstein V, Leveque J, Mathevet P, Raulic P, Baldauf JJ, et al. Regression of high-grade cervical intraepithelial neoplasia with TG4001 targeted immunotherapy. Am J Obstet Gynecol. 2011;204:169.e1-8.

31. Rosales R, López-Contreras M, Rosales C, Magallanes-Molina JR, Gonzalez-Vergara R, Arroyo-Cazarez JM, et al. Regression of human papillomavirus intraepithelial lesions is induced by MVA E2 therapeutic vaccine. Hum Gene Ther. 2014;25:1035-49.

32. Santin AD, Bellone S, Palmieri M, Zanolini A, Ravaggi A, Siegel ER, et al. Human papillomavirus Type 16 and 18 E7-pulsed den- dritic cell vaccination of stage IB or IIA cervical cancer patients: a Phase I escalating-dose trial. J Virol. 2007;82:1968-79.

33. Majewski S, Bosch F, Dillner J, Iversen OE, Kjaer SK, Muñoz N et al. The impact of a quadrivalent human papillomavirus (Types $6,11,16,18$ ) virus-like particle vaccine in European women aged 16 to 24. J Eur Acad Dermatol Venereol. 2009. 23:1147-55

34. Kjaer SK, Sigurdsson K, Iversen OE, Hernandez-Avila M, Wheeler CM, Perez G, et al. A pooled analysis of continued prophylactic efficacy of quadrivalent human papillomavirus (Types $6 / 11 / 16 / 18$ ) vaccine against high-grade cervical and external genital lesions. Cancer Prev Res. 2009;2:868-78.

35. Garland SM, Hernandez-Avila M, Wheeler CM, Perez G, Harper DM, Leodolter $S$, et al. Quadrivalent vaccine against human papillomavirus to prevent anogenital diseases. N Engl J Med. 2007; 356:1928-43.

36. Hildesheim A, Herrero R, Wacholder S, Rodriguez AC, Solomon D, Bratti MC, et al. Effect of human papillomavirus 16/18 L1 viruslike particle vaccine among young women with preexisting infection: a randomized trial. J Am Med Assoc. 2007; 298:743-53.

37. Arbyn M, Xu L, Simoens C, Martin-Hirsch PP. HPV vaccination to prevent cancer and pre-cancerous changes of the cervix. Cochrane Database Syst Rev. 2018;5:CD009069. 